\title{
RESEARCH ARTICLE SERUM SYNDECAN-1 AND APOLIPOPROTEIN A1 IN PATIENTS WITH CHRONIC HCV INFECTION
}

\author{
*,1Nagwa S. Ahmed, ${ }^{1}$ Mohamed Ahmed Abdelmoaty, ${ }^{2}$ Tahia H. Saleem, \\ ${ }^{3}$ Ghada M. Galal and \\ 1 Amira Morad \\ 1Departments of Medical Biochemistry, Faculty of Medicine, Sohag \\ 2Departments of Medical Biochemistry, Assuit University \\ 3 Tropical Medicine and Gastroenterology, Faculty of Medicine, Sohag
}

\begin{abstract}
Hepatitis $\mathrm{C}$ virus (HCV) is endemic in Egypt. Over 15\% of populations of the people in Egypt are infected, this is ten times greater than in any other country in the world. To validate a simple, inexpensive, non invasive markers (Fib-4, APRI, syndecan-1 and apolipoprotein A-1(ApoA-1) for detection of liver fibrosis in patients with chronic HCV and thereby reduce the need for liver biopsy. Estimation of serum syndecan-1 and apoA-1 by ELISA were done on 20 normal healthy persons and 57 chronic hepatitis $\mathrm{C}$ patients, the patients were staged according to liver biopsies (Metavir fibrosis staging) (stage $\mathrm{f} 1=15$, $\mathrm{f} 2=15, \mathrm{f} 3=14, \mathrm{f} 4=13$ ). The area under the receiver operating characteristic (ROC) curve (AUC) of syndecan$1=(0.72)$, the mean level of plasma syndecan- 1 was significantly higher in chronic $\mathrm{HCV}$ patients when compared to control subjects $(\mathrm{P}=0.0008)$, but the mean level of ApoA-1 was not significantly different from that of controls $(\mathrm{p}=0.65)$, and it had significant negative correlation to the stage of fibrosis (AUC $=0.57$ ). Moreover the APRI and Fib-4 were proved significantly directly correlated with fibrosis stage of the studied patients. This study not reveals putative biomarkers of liver fibrosis (syndecan-1, ApoA-1 APRI, Fib-4) but also proves the differential expression of those markers in different stages of fibrosis. It is expected that combination of these novel biomarkers could be applied clinically to predict the stage of liver fibrosis without the need of liver biopsy.

Copyright (C) 2015 Nagwa S. Ahmed et al. This is an open-access article distributed under the Creative Commons Attribution License, which permits unrestricted use, distribution, and reproduction in any medium, provided the original work is properly cited.

Keywords:Syndecan-1, ApoA-1,Chronic hepatitis C, Non-invasive marker, Liver biopsy.
\end{abstract}

\section{INTRODUCTION}

Hepatitis C virus (HCV) infects 170 million people worldwide and is thus a major public health problem (Thomas et al., 2000; world health organization 2012). The infection is often asymptomatic, but chronic infection can lead to scarring of the liver and ultimately to cirrhosis, which is generally apparent

Among a variety of causes/factors or stimuli, which bring about this transformation are: chronic infection by hepatitis B, C viruses and parasites as Schistosoma spp, chronic alcoholism and/or exposure to certain drugs and toxins, infections, nonalcoholic steatohepatitis (NASH), inherited metabolic diseases like hemochromatosis, Wilson's disease, $\alpha-1$ antitrypsin 
after many years. In some cases, those with cirrhosis will go on to develop liver failure, liver cancer or life-threatening esophageal and gastric varices (Ryan et al., 2004).

Liver fibrosis results from chronic damage to the liver in conjunction with progressive accumulation of fibrillar matrix

deficiency, autoimmune diseases "extracellular matrix" proteins (ECM). Hepatic fibrosis (HF) is a pathological condition resulting in abnormal proliferation and accumulation of tough fibrous connective tissue (scar

Although the current gold tissue) in the liver. Although the formation of scar tissue is a normal body response to injury, in fibrosis, this healing

patients to undergo repeated process goes erroneous. Normal process of wound healing involves collagen deposition; however, the chronic activation

of this healing mechanism leads to liver pathology.

the first approach used to assess the *Corresponding author: Nagwa S. Ahmed,

Departments of Medical

Biochemistry, Faculty of Medicine,

Sohag

noninvasive means consisted of routine biochemical and/or hematological tests (Marti'nez et al., 2011). These so-called

class II biomarkers are indirect

fibrosis (Gressner et al.,1994). Decorin is the most extensively studied proteoglycan in liver fibrosis (Hogemann et al., 1997; Dudas et al., 2001) followed by biglycan, perlecan, aggrecan (in rodents), syndecan and lumican all showing elevated levels as a response to chronic liver injury. Syndecan-1 and -2 are increased on both mRNA and protein levels in the cirrhotic livers (Jarnagin et al., 1994). such as primary biliary

cirrhosis, and autoimmune hepatitis (Friedman, 2008). Monitoring of progression of liver fibrosis is an important tool for the clinician in assessing the aggressiveness of infection and the level of hepatic injury. For treatment decisions and prognosis, the accurate staging of hepatic fibrosis is essential.

standard is a liver biopsy, this the procedure is limited by invasiveness, complications, sampling error, variability in interpretation, and the reluctance of

to monitor disease

biopsies progression (Bedossa et al., 2006; Friedman, 2004). Due to

these limitations, numerous studies have examined

noninvasive measures for the prediction of HCV-related fibrosis (Afdhal and Nunes 2004, Parkes et al., 2006). The degree of liver fibrosis by

Syndecan-1 (CD 138) is one of four members of a family of serum markers and are based on the evaluation of common functional alterations in the liver, alterations that do not necessarily reflect extracellular matrix turnover and/or fibrogenic cell changes. APRI (Wai et al., 2003), Forns index (Forns et al., 2002) and Fib4 (Sterling et al., 2006) are examples of this class. More recently, a better understanding of the pathophysiology of liver fibrosis has prompted many investigators to use more refined markers to identify different fibrosis stages. The latter, termed class I biomarkers, are those intended to detect extracellular matrix turnover and/or fibrogenic cell changes. These include Fibrometer (Cales et al., 2005) and Enhanced Liver Fibrosis panel (ELF) score 
SOHAG MEDICAL JOURNAL RESEARCH ARTICLE SERUM SYNDECAN-1

Vol. 23 No.2 Apr 2019

Amira Morad.et al

(Rosenberg et al., 2004) 
Thus, it is not very far that this invasive method will be completely replaced by other noninvasive methods such as serum based biomarkers (Parsian et al., 2012). (Heinegard and Oldberg, 1989). In the liver, proteoglycans are localized to the extracellular, pericellular spaces and on the cell surface, where they participate in cell-cell, cellmatrix and protein-protein interactions (Jarnagin, et al., 1994). In the normal liver, the net amount of proteoglycans is low (MartinezHernandez and Amenta, 1993), whereas the level of several proteoglycans is increased during liver transmembrane heparan sulfate proteoglycans with distinct expression patterns and function. CD138 is a new simple non- invasive marker for predicting liver fibrosis in patients with chronic hepatitis $\mathrm{C}$. Apolipoprotein A-I (apoA-I) is a single polypeptide of 243 amino acids with a molecular mass of 28.1 $\mathrm{kDa}$, mainly present in plasma as a component of high density lipoprotein (HDL) (Zannis et al., 2004). ApoA-I is expressed primarily by the intestine and the liver, although other tissues also express it. Serum concentration of apolipoprotein A1 was incorporated with other serum markers in the assessment of liver fibrosis (ImbertBismut et al., 2001; Gangadharan et al., 2007) and it was reported to be negatively correlated with the stage of liver fibrosis.

\section{Aim of the work}

The aims of the present study are: 1) to assess the level of Syndecan- 1 (CD138) and apolipoprotein A-1 in patients with chronic HCV infection in comparison to healthy controls. 2) to test the diagnostic accuracy of these novel biomarkers in comparison to previously validated ones (as APRI and FIB-4) as non-invasive markers for differentiating mild from advanced stages of liver fibrosis.

\section{Patients and Methods Patients}

Fifty-seven patients with positive

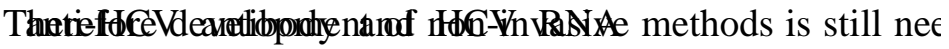
by PCR for more than 6 months and referred for liver biopsy were recruited for the study from the Tropical Medicine \& Gastroenterology Department, Sohag University Hospital. The study was approved by the local institutional ethical committee and patient's consent was obtained. In addition, twenty healthy (with no evidence of acute or chronic liver disease or other medical disorders), adult age and sexmatched individuals were recruited as a control group. Liver biopsy was performed for all patients to assess the severity of fibrosis (staging) and inflammation (grading) prior to

Epithtehiahcells primarily express syndecan-1, and observati Exclusion criteria were as follows: any disorders associated with extrahepatic fibrosis, decompensated liver cirrhosis, hepatitis B coinfection, hepatomegaly due to autoimmune disease, fatty liver, liver failure, hepatocellular carcinoma, uncontrolled diabetes mellitus and nephrotic syndrome.

\section{Methods}

\section{All patients were subjected to the} following:

1- Complete medical history taking, clinical and radiological examination

2- The histological evaluation of paraffin-embedded liver specimens was carried out at the Pathology Department, Sohag University Hospital, according to METAVIR scoring system (Bedossa and Poynard, 2006). Liver biopsies were evaluated by two independent pathologists without prior information to patient's history. Histological staging based on the degree of fibrosis: as F0 (no fibrosis), F1 (mild fibrosis without septa), F2 
(moderate fibrosis with few septa), F3 (severe fibrosis with numerous septa without cirrhosis) and F4 (cirrhosis).

3- Abdominal Imaging: ultrasound was done to evaluate liver size, each pattern (normal, bright or coarse), regularity of the surface, presence of splenomegaly, dilated portal vein or presence of portosystemic collaterals and ascites.

4- Blood sampling:

Four $\mathrm{ml}$ of blood were collected from all patients and controls, and left to clot for 20-30 $\mathrm{min}$ at room temperature and followed by centrifugation at 1500 r.p.m for 10 min. The serum was then transferred to a polypropylene tube and kept frozen at $-80^{\circ} \mathrm{C}$ until assayed. Serum ALT, AST, alkaline phosphatase, albumin and total bilirubin concentrations were measured using standard methodologies. Hemoglobin concentration was determined by a colorimetric method. Red blood corpuscles, white blood cells and platelets were counted by hemocytometer apparatus. All biochemical tests were done without knowledge of liver biopsy results and all patients were evaluated for, APRI and FIB-4, indexes. The following formulas were used to calculate the predicted scores.

APRI (Wai et al., 2003) $=[\{$ AST (IU/l)/ ALT_ULN (IU/l) $\} \times$

$100] /$ platelet count $\left(10^{9} / 1\right)$.

FIB-4 (Sterling et al., 2006) (= [Age $($ Years $) \times$ AST $($ IU/l)] $/[$ Platelet count $\left.\left(\times 10^{9} / 1\right) \times \operatorname{ALT}(\mathrm{IU} / \mathrm{l})^{1 / 2}\right]$.

Serum Apolipoprotein A1 (Apo A1): from Assaypro and syndecan-1 from Wake was used. They were a solid phase capture sandwich ELISA assay using a microwell format.

\section{Statistical analysis}

Data were analyzed using STATA intercooled version 9.2. Quantitative data were analyzed using student t- test to compare means of two groups and ANOVA for comparison of the means of three groups or more. When the data were not normally distributed Mann-Whitney test was used. Qualitative data were compared using either Chi square test or fisher exact test. univariate and multivariate logistic regression analysis was used to identify data that predict advanced fibrosis. Data were analyzed by sensitivity, specificity, positive, and negative predictive value derived from the receiver operating characteristic (ROC) curve by using Medcalc for Windows (version 11.0) and STATA (version 9.2). The diagnostic accuracy of syndecan-1, apolipoprotein- A-1, Fib-4, and APRI for detecting advanced fibrosis was expressed as the area under the ROC curve (AUC). $\mathrm{P}$ value was considered significant if it was less than 0.05 . 
SOHAG MEDICAL JOURNAL

Vol. 23 No. 2 Apr 2019

\section{RESULTS}

The demographic and clinical data of all patients are illustrated in Table (1).

Table 1. Clinical data of the studied group

\begin{tabular}{ll}
\hline Clinical data & Patients $(\mathrm{n}=57)$ \\
\hline Age & $39.8 \pm 10.5$ \\
Sex & $18(31.6 \%)$ \\
Female & $39(68.4 \%)$ \\
male & \\
BMI $\left(\mathrm{Kg} / \mathrm{m}^{2}\right) \mathrm{DM}(\%)$ & $24.5 \pm 3.75$ \\
No & $47(82.5 \%)$ \\
Yes Hypertension & $10(17.5 \%)$ \\
No & $49(86 \%)$ \\
Yes Pallor & $8(14 \%)$ \\
No & $54(94.7 \%)$ \\
Yes & $3(5.3 \%)$ \\
Jaundice (No) & $57(100 \%)$ \\
Liver size by U/S & \\
Normal & $29(50.9 \%)$ \\
Hepatomegaly & $15(26.3 \%)$ \\
Shrunken liver & $13(22.8 \%)$ \\
Splenomegaly & \\
normal & $41(71.9 \%)$ \\
enlarged & $16(28.1 \%)$ \\
Ascites (No) & $57(100 \%)$ \\
Hepatic focal lesion $($ No) & $57(100 \%)$ \\
\hline All data are mean \pm SD or proportions $[\mathrm{N}(\%)]$, \\
\end{tabular}


Table (2) shows a comparison of laboratory data between patients and controls. Serum syndican-1 was significantly elevated in patients compared to the controls. While, Apo-1 was insignificantly higher in patients in comparison with the controls.

Table 2. Laboratory characteristics of the studied groups

\begin{tabular}{llll}
\hline & Patients & Control & P value \\
\hline ALT (IU/L) & $66.75 \pm 76.16$ & $19.5 \pm 3.17$ & $<0.001$ \\
AST(IU/L) & $52.68 \pm 54.57$ & $18.55 \pm 3.95$ & $<0.001$ \\
TBil (mg/dl) & $0.85 \pm 0.43$ & $0.89 \pm 0.11$ & $=0.045$ \\
Total Protein & $7.66 \pm 0.71$ & $7.42 \pm 0.33$ & $=0.002$ \\
(g/dl) & & & \\
Albumin & $3.93 \pm 0.54$ & $3.95 \pm 0.34$ & $=0.005$ \\
(g/dl) & & & \\
INR & $1.15 \pm 0.25$ & $0.95 \pm 0.1$ & $<0.0003$ \\
$\begin{array}{l}\text { Prothrombin } \\
\text { Conc. \% }\end{array}$ & $84.89 \pm 15.76$ & $98 \pm 1.78$ & $<0.0001$ \\
$\begin{array}{l}\text { FBG (mg/dl) } \\
\text { HB(gm/dl) }\end{array}$ & $103.64 \pm 22.71$ & $95.15 \pm 9.16$ & 0.28 \\
$\begin{array}{l}\text { WBCs } \\
\text { (x103/mm3) }\end{array}$ & $6.16 \pm 2.05$ & $7.4 \pm 1.05$ & $<0.0001$ \\
$\begin{array}{l}\text { Platelets } \\
\text { (x109/L) }\end{array}$ & $220.55 \pm 65.25$ & $255.9 \pm 33.6$ & 0.03 \\
$\begin{array}{l}\text { Syndecan-1 } \\
\text { (pg/ml) }\end{array}$ & $5.60 \pm 2.426$ & $4.155 .6 \pm 3.98$ & 0.008 \\
$\begin{array}{l}\text { ApoA-1 } \\
\text { (mg/dl) }\end{array}$ & $81.66 \pm 97.19$ & $74.55 \pm 48.42$ & 0.65 \\
\hline $\begin{array}{l}\text { All data are } \\
\text { (mon }\end{array}$ & & & \\
\hline
\end{tabular}

All data are mean \pm SD. AST, aspartate amino- transferase; ALT, anlanine amino transferase; T.Bil, total billirubin; TP total protein., FBG, fasting blood glucose., $\mathrm{HB}$, heamoglobin, WBCs., White blood corpuscles., ( $t$-test for continuous variables), $* P<0.05$.

According to the results of Metavir histological staging and grading, patients were categorized into either $\mathrm{F} 0=(0 \%), \quad \mathrm{F} 1=(26.31 \%), \quad \mathrm{F} 2=(26.31), \quad \mathrm{F} 3=(24.56)$, $\mathrm{F} 4=(22.80)$. This is

illustrated in Table (3)

Table 3. Liver fibrosis

\begin{tabular}{ll}
\hline & N\% \\
\hline F1 & $15(26.31 \%)$ \\
F2 & $15(26.31 \%)$ \\
F3 & $14(24.56 \%)$ \\
F4 & $13(22.80 \%)$ \\
(Cirrhosis) & \\
\hline
\end{tabular}


SOHAG MEDICAL JOURNAL Vol. 23 No.1 Jan 2019
Leptin and Tumor necrosis factor -alpha in breast Asmaa Hussein.et al

Table 4. Comparison between mild and advanced fibrosis as regard demographic and laboratory data

\begin{tabular}{|c|c|c|c|}
\hline & $\begin{array}{l}\mathrm{F} 1+\mathrm{f} 2 \\
(\mathrm{n}=30)\end{array}$ & $\begin{array}{l}\mathrm{F} 3+\mathrm{f} 4 \\
(\mathrm{n}=27)\end{array}$ & $\begin{array}{l}\mathrm{P} \\
\text { value }\end{array}$ \\
\hline $\begin{array}{l}\text { Age } \\
\operatorname{BMI}\left(\mathrm{Kg} / \mathrm{m}^{2}\right) \operatorname{Sex}\end{array}$ & $\begin{array}{l}38.43 \pm 10 . \\
50 \\
23.60 \pm 3.1 \\
1\end{array}$ & $\begin{array}{l}41.37 \pm 10 . \\
49 \\
25.44 \pm 4.2 \\
0\end{array}$ & 0.30 \\
\hline Females & $7(23.33 \%)$ & 11(40.74\% & 0.16 \\
\hline Males & $23(76.67 \%$ & $16(59.26 \%$ & \\
\hline ALT(IU/L) & $\begin{array}{l}\text { ) } \\
58.70 \pm 57 \text {. } \\
67\end{array}$ & $\begin{array}{l}\text { ) } \\
75.59 \pm 91 \text {. } \\
7\end{array}$ & 0.24 \\
\hline AST(IU/L) & $\begin{array}{l}44.90 \pm 16 \\
55\end{array}$ & $\begin{array}{l}61.89 \pm 76 . \\
46\end{array}$ & 0.37 \\
\hline TBil (mg/dl) & $\begin{array}{l}0.66 \pm 0.24 \\
9\end{array}$ & $1.04 \pm 0.49$ & 0.005 \\
\hline $\begin{array}{l}\text { Total Protein } \\
(\mathrm{g} / \mathrm{dl})\end{array}$ & $\begin{array}{l}7.94 \pm 0.61 \\
2\end{array}$ & $7.35 \pm 0.66$ & 0.001 \\
\hline $\mathrm{HB}(\mathrm{gm} / \mathrm{dl})$ & $\begin{array}{l}14.00 \pm 1.8 \\
0\end{array}$ & $\begin{array}{l}13.68 \pm 1.8 \\
5\end{array}$ & 0.52 \\
\hline $\begin{array}{l}\text { WBCs } \\
\left(\times 10^{3} / \mathrm{mm}^{3}\right)\end{array}$ & $5.70 \pm 1.63$ & $6.65 \pm 2.33$ & 0.07 \\
\hline Platelets $\left(\times 10^{9} / \mathrm{L}\right)$ & $\begin{array}{l}245.6 \pm 46 . \\
42\end{array}$ & $\begin{array}{l}192.8 \pm 71 \text {. } \\
27\end{array}$ & 0.002 \\
\hline $\operatorname{Albumin}(\mathrm{g} / \mathrm{dl})$ & $\begin{array}{l}4.160 \pm 0.4 \\
53\end{array}$ & $\begin{array}{l}3.65 \pm 0.49 \\
9\end{array}$ & 0.0002 \\
\hline INR & $\begin{array}{l}1.023 \pm 0,0 \\
77\end{array}$ & $1.27 \pm 0.29$ & 0.001 \\
\hline $\begin{array}{l}\text { Prothrombin } \\
\text { Conc. } \%\end{array}$ & $\begin{array}{l}93.10 \pm 7.1 \\
6\end{array}$ & $\begin{array}{l}75.81 \pm 17 \\
49\end{array}$ & 0.0002 \\
\hline $\mathrm{FBG}(\mathrm{mg} / \mathrm{dl})$ & $\begin{array}{l}100.9 \pm 18 \text {. } \\
29\end{array}$ & $\begin{array}{l}106.8 \pm 26 . \\
98\end{array}$ & 0.41 \\
\hline $\begin{array}{l}\text { Syndecan } \\
(\mathrm{pg} / \mathrm{ml})\end{array}$ & $\begin{array}{l}4.598 \pm 9.2 \\
1\end{array}$ & $\begin{array}{l}6.715 \pm 3.0 \\
4\end{array}$ & 0.005 \\
\hline apoA-1 (mg/dl) & $\begin{array}{l}83.61 \pm \\
126.4\end{array}$ & $\begin{array}{l}79.91 \pm 62 . \\
52\end{array}$ & 0.36 \\
\hline $\begin{array}{l}\text { FIB-4 } \\
\text { APRI }\end{array}$ & $\begin{array}{l}1.06 \pm 0.60 \\
0 . \quad 48 \quad \pm \\
0.18\end{array}$ & $\begin{array}{l}1.56 \pm 0.73 \\
0 . \quad 71 \pm 0 . \\
36\end{array}$ & $\begin{array}{l}0.004 \\
0.009\end{array}$ \\
\hline
\end{tabular}


SOHAG MEDICAL JOURNAL

Vol. 23 No.1 Jan 2019
Leptin and Tumor necrosis factor -alpha in breast

Asmaa Hussein.et al

Performance of serum fibrosis markers for prediction of advanced fibrosis (stage 3 and 4)

For evaluation of the performance of serum fibrosis markers in prediction of advanced fibrosis, their results were compared with that of liver histopathology taken as a gold standard. For each serum fibrosis marker, sensitivity, specificity, positive and negative predictive values were calculated at different cut- offs and ROC curve analysis was performed for them. Table

(5) show that syndecan-1 at a cut off $(>5.917)$ has an area under curve $(\mathrm{AUC}=0.72)$ similar to APRI and Fib4. However, it shows the best sensitivity (although unsatisfactory), best specificity and highest PPV and NPV. Fig (1) shows comparison of the AUC of the 4 tested serum fibrosis markers.

minority suffers from long term complications (Chen and Morgan, 2006).

At present the diagnosis of liver fibrosis still depends on pathological examination of liver biopsy, which is an invasive procedure, associated with patient discomfort and in rare cases with serious complications (Thampanitchawong and Piratvisuth, 1999). In addition, the accuracy of liver biopsy is limited due to sampling error and significant Intra and inter-observer variability in histological examination (Regev et al., 2002). Non invasive assessment of liver histology has been the focus of research for many years, which is important to measure the severity of liver injury in Egypt where advanced liver disease from $\mathrm{HCV}$ is common.

Table 5. Sensitivity, specificity, PPV and NPV of syndican-1, apoA1, FIB-4 and APRI to diagnose correctly advanced fibrosis

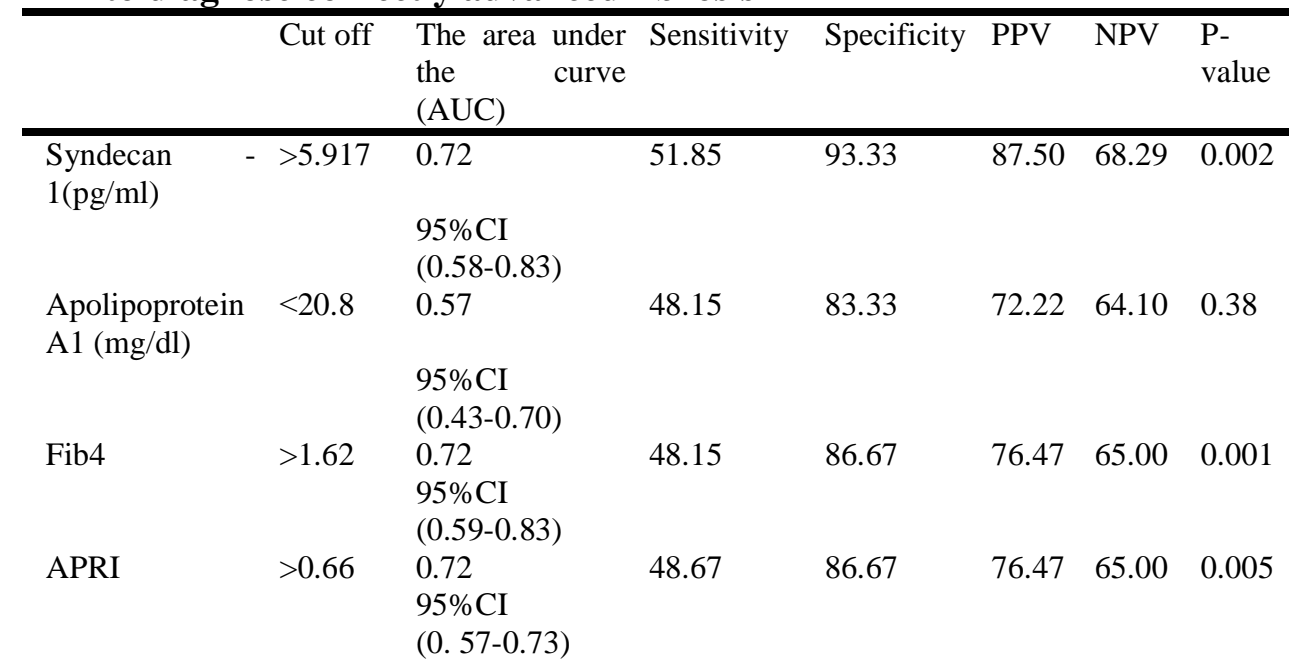

Univariate analysis to the significant variables, ${ }^{*} P<0.05 \mathrm{PPV}$, positive predictive value; NPV, negative predictive value

We have tested the possibility that the presence in the serum of cell surface proteoglycans shed by cells in several pathological conditions may correlate with liver fibrosis. The proteoglycans we investigated are the syndecan family, which are transmembrane glycoproteins with either heparan sulphate or chondroitin sulphate chains (Kim et al., 1994). In the present study, the syndecan level was increased significantly from mild to advanced fibrosis at a cut off $>5.91$ with AUC (0.72), specificity (86.67) the PPV (76.47) and the NPV (65.00). These results are comparable to those of Zvibel et al. (2008) in chronic hepatitis C patients. 


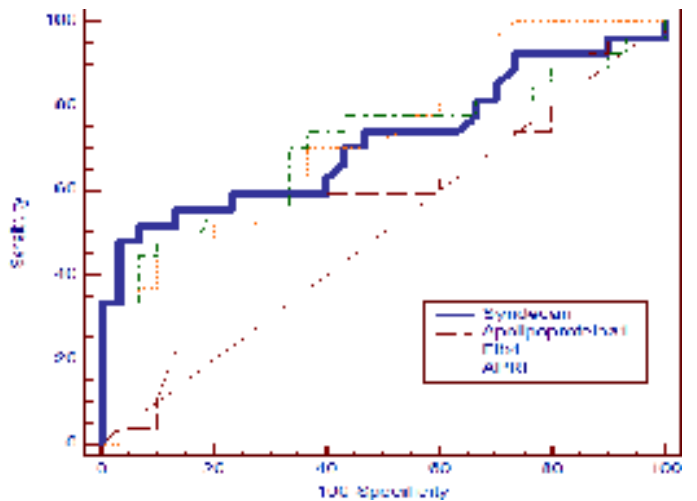

\section{DISCUSSION}

The liver is of vital importance in intermediate metabolism, detoxification and elimination of toxic substance (Gressner., 1998). Damage of this organ affects liver function tests. Liver fibrosis, a common sequel of chronic inflammatory liver disease, is a complex dynamic process that includes an increase in ECM components, activation of cells producing matrix material, cytokine release and tissue remodeling (Vozar., 2005). The rate of fibrosis progression in HCV patients varies markedly from person to person, and only a

Syndecans can exert their effect by acting as co-receptors to various growth factors such as basic fibroblast growth factor and regulate their activity. It interacts with growth factors, matrix components and other extracellular proteins and is thought to be involved in processes such as cell growth, differentiation and adhesion. (CD138) is a marker of liver fibrosis, because it was shown to be present in high amounts in wound fluids (Subramanian et al., 1997, Kainulainen et al., 1998). Syndecan-1 is shed by many cell types during pathological processes, and it was also found to be a prognostic marker for myelomas and small cell lung cancer (Anttonen et al., 2003, Seidel et al., 2000).

In the current study, we noted an insignificant decrease in serum
Fig. 1. Receiver operating characteristic (ROC) curves of different biomarkers to predict advanced fibrosis

Apolipoprotein-A1 in patients with advanced fibrosis compared to those with mild fibrosis. Miller et al. (1980) reported that ApolipoproteinA-1 is synthesized by the liver, and it is included in extracellular matrix and its level is decreased at increasing stages of fibrosis. In alcohol-induced liver disease, serum Apo A-I increases in patients with normal liver, steatosis, and decreases in liver fibrosis and cirrhosis (Poynard et al., 1987). Recently, Kim et al., 2010 reported that ApoA-1 is expressed in the lung epithelium, that lung ApoA1 levels were reduced in patients with idiopathic pulmonary fibrosis, ApoA-1 protects against ongoing fibrosis and promotes the resolution of established experimental lung silicosis., (Lee et al., 2013) this is agree with our results, Imbert-Bismut et al. (2001) found that of ApoA-1 together with other five serum fibrosis markers can substantially reduce the numbers of liver biopsies in chronic HCV patients. Also Myers et al. (2003) reported that GGT, AST, and apolipoprotein A1 were independently predictive of significant fibrosis in chronic hepatitis B 
The mechanisms of serum Apo A-I decrease in liver fibrosis are unknown. During liver fibrosis, several hypotheses can be evoked: .a decrease in Apo A-I transcription, an increase in Apo A-I catabolism, or storage of Apo A-I by the developing ECM. The latter hypothesis suggesting that Apo A-I interacts with the ECM is supported by several arguments. First, immunohistochemical studies have shown that Apo A-I colocalizes with ECM. Another argument is that lipoproteins can be extracted from vessels only in association with constituents of the ECM (Bedossa et al., 1989). Apolipoprotein A-1 serum concentration is associated with fibrosis and used with prothrombin and GGT as a serum marker. (Teare et al., 1993, Naveau et al., 1994, Poynard et al., 1991) It is trapped on extracellular matrices (Paradis et al., 1996) Apolipoproteins, especially $\mathrm{A}_{-2}$, (Sabile et al., 1999) also interact with $\mathrm{HCV}$ capsid proteins

Our results show that APRI and Fib 4 score were significantly increased from stage $\mathrm{F} 1$ to $\mathrm{F} 4$ according to Metavir classification. We found that at a cut off for APRI >0.66 with AUC(0.72), the specificity (86.67) the PPV(76.47) and the NPV(65.00). APRI was initially described by Wai et al. (2003). This index is dependent on two routine tests, i.e. aspartate aminotransferase and platelet count. In a study by Snyder et al. (2006) for validation of APRI a value of $<0.42$ were accurately predicting mild fibrosis, whereas a value $>1.2$ were accurately predicting significant fibrosis, these conflicting results may be due to difference in numbers of the patients, histopathological scoring system used, and/or prevalence of the diseases. Le Calvez et al. (2004) reported that APRI and Forn's index were not able to identify individual stages of fibrosis, where APRI cannot be completely standardized due to variability in normality ranges of AST in different laboratories.

Other simple index that related to age (years), AST and ALT levels (U/L) and platelet count, is FIB-4. Yang et al. (2012) reported that FIB-4 index had a significant power for differentiation between patients with mild and significant fibrosis in nonalcoholic fatty liver disease (NAFLD), and they reported that FIB-4 might be useful as a non invasive hepatic fibrosis scores for predicting hepatic fibrosis in patients with NAFLD. Shah et al. (2009) in a study on 541 NAFLD adults found that among various serum based algorithms, FIB4 had better diagnostic accuracy for estimation of liver fibrosis. Our result is less at cut off >1.62 with AUC (0.72), the specificity (86.67) the PPV (76.47) and the NPV (65.00). The FIB-4

index may be of value in several respects. First, it is easy to use; the calculations are simple, quick, and do not require standardization. Second, results are available immediately, during the patient's visit. Third, it is inexpensive; there is no need to invest in a costly apparatus, and there are no additional costs, because the constitutive FIB-4 parameters are included in the standard investigation of any liver disease (age, AST, ALT, platelet count) (Pichard et al., 2007).

In conclusion, the non-invasive methods will reduce but not completely abolish the need for liver biopsy. The most rational way of using these tools is to make a compromise: use non- invasive methods to classify those patients in whom they perform with high accuracy, sensitivity and the specificity for limiting liver biopsy to the subset of patients in whom precise noninvasive staging is not possible. Also syndecan-1 and ApoA- 
1 are non invasive markers for predicting liver fibrosis. Application of biomarkers would provide the clinicians with improved tools to personalize the treatment, to follow the progression of the disease and to monitor the response to treatment.

\section{REFERENCES}

1. Afdhal, NH. and Nunes, D. 2004. Evaluation of liver fibrosis: a concise review. Am J Gastroenterol.; 99(6):1160-1174.

2. Anttonen A, Leppä S, Ruotsalainen T, Alfthan $\mathrm{H}$, Mattson K, Joensuu H. 2003. Pretreatment serum syndecan-1 levels and outcome in small cell lung cancer patients treated with platinum-based chemotherapy. Lung Cancer, 41:171-7.

3. Bedossa, P. and Poynard, T. 1996. An algorithm for the grading of activity in chronic hepatitis C. The METAVIR Cooperative Study Group. Hepatology, 24 (2):289-93.

4. Bedossa, P., Dargere, D. and Paradis V. 2003. Sampling variability of liver fibrosis in chronic hepatitis C. Hepatology, 38(6): 1449-1457

5. Bedossa, P., Poynard T., Abella A., Paraf F., Lemaigre, $G$ and Martin, ED. 1989. Localization of apolipoprotein A-I and apolipoprotein A-II in normal and atherosclerotic arteries. Arch Pathol Lab Med., 113:777-780.

6. Calès P1., Oberti F., Michalak S., HubertFouchard I., Rousselet MC., Konaté A., Gallois Y., Ternisien C., Chevailler A. and Lunel F. 2005. A novel panel of blood markers to assess the degree of liver fibrosis. Hepatology, 42:1373-1381.

7. Chen SL. and Morgan TR. 2006. The natural history of hepatitis $\mathrm{C}$ virus (HCV) infection. Int $J$ Med Sci., 3 : 47-52. Dudas J., Kovalszky I., Gallai M., Nagy J.O, Schaff Z., Knittel T., Mehde M., Neubauer K., Szalay F. and Ramadori G.

8. 2001. Expression of decorin, transforming growth factor- beta 1, tissue inhibitor metalloproteinase 1 and 2 , and type IV collagenases in chronic hepatitis, Am J Clin Pathol., 115, 725-735.

9. Forns X., Ampurdanès S., Llovet JM., Aponte J., Quintó L., Martínez-Bauer E., Bruguera M., Sánchez- Tapias JM. and Rodés J. 2002. Identification of chronic hepatitis C patients without hepatic fibrosis by a simple predictive model. Hepatology, 36:986-992.

10. Friedman LS. 2004. Controversies in liver biopsy: who, where, when, how, why? Curr Gastroenterol Rep., 6(1): 30-36.

11. Friedman SL. 2008. Mechanism of hepatic fibrogenesis.

12. Gastroenterology, 134:165569.

13. Gangadharan B., Antrobus R., Dwek RA. and Zitzmann N 2007. Novel Serum Biomarker Candidates for Liver Fibrosis in Hepatitis C Patients. Clinical Chemistry, 53:1792-1799.

14. Gressner A.M., Krull N. and. Bachem M.G. 1994. Regulation of proteoglycan expression in fibrotic liver and cultured fatstoring cells. Pathol Res Pract., 190, 864-882

15. Gressner AM. 1998. The cell biology of liver fibrogenesis an imbalance of proliferation growth arrest and apoptosis of myofibroblasts. Cell Tissue Res., 292:447-52. 
16. Heinegard D. and Oldberg A. 1989. Structure and biology of cartilage and bone matrix noncollagenous macromolecules, FASEB J3, 2042-2051.

17. Hogemann B., Edel G., Schwarz K., Krech R. and Kresse H. 1997. Expression of biglycan, decorin and proteoglycan100/CSF-1 in normal and fibrotic human liver, Pathol Res Pract193, 747-751.

18. Imbert-Bismut F., Ratziu V., Pieroni L., Charlotte F., Benhamou Y. and Poynard T. 2001. Biochemical markers of liver fibrosis in patients with hepatitis $\mathrm{C}$ virus infection: a prospective study. Lancet, 357:1069-1075.

19. Jarnagin W.R., Rockey D.C., Koteliansky V.E., Wang S.S and. Bissell D.M. 1994. Expression of variant fibronectins in wound healing: cellular source and biological activity of the EIIIA segment in rat hepatic fibrogenesis, J Cell Biol., 127 :2037-2048.

20. Kainulainen V., Wang $H$., Schick C. and Bernfield M. 1998. Syndecans, heparan sulfate proteoglycans, maintain the proteolytic balance of acute wound fluids. J Biol Chem., 273: 11563-9.

21. Kim CW., Goldberger OA., Gallo RL. and Bernfield, M. 1994. Members of the syndecan family of heparan sulfate proteoglycans are expressed in distinct cell-, tissue- and development-specific patterns. Mol Biol Cell., 5: 797-805.

22. Kim TH., Lee YH., Kim KH., Lee SH., Cha JY., Shin EK., Jung S., Jang AS., Park SW., Uh ST., Kim YH., Park JS., Sin HG., Youm W., Koh ES., Cho SY., Paik YK., Rhim TY. and
Park CS. 2010. Role of lung apolipoprotein A-I in idiopathic pulmonary fibrosis: antiinflammatory and antifibrotic effect on experimental lung injury and fibrosis. Am J Respir Crit Care Med., 182: 633-642.

23. Le Calvez S., Thabut D., Messous D., Munteanu M., Ratziu V., Imbert-Bismut F. and Poynard, T. 2004. The predictive value of Fibrotest vs. APRI for the diagnosis of fibrosis in chronic hepatitis C., Hepatol; 39:862-3.

24. Lee EH., Lee EJ., Kim HJ., Jang AS., Koh ES., Kim Y., Park,

25. S. and Park, C. 2013. Overexpression of Apolipoprotein A1 in the Lung Abrogates Fibrosis in Experimental Silicosis. PLoS ONE 8(2): e55827.

26. Li Q., Park PW., Wilson CL. and Parks WC. 2002. Matrilysin shedding of syndecan-1 regulates chemokine mobilization and transepithelial efflux of neutrophils in acute lung injury. Cell, 111:635.

27. Martı́nez S M., Crespo G., Navasa M. and Forns X. 2011. Noninvasive Assessment of Liver Fibrosis: Hepatology, 53:325-335

28. Martinez-Hernandez and Amenta P.S. 1993. The hepatic extracellular matrix. I. Components and distribution in normal liver, Virchows Arch A Pathol Anat Histopatho. 1423, 111.

29. Miller GJ. 1980. High density lipoproteins and atherosclerosis.

30. Апnu Rev Med., 31:97-108.

31. Myers RP., Benhamou Y., Imbert-Bismut F., Thibault V., Bochet M., Charlotte F., Ratziu V., Bricaire F., 
Katlama C. and Poynard T. 2003. Serum biochemical markers accurately predict liver fibrosis in HIV and hepatitis C viruscoinfected patients. AIDS; 17:721-5.

32. Naveau S., Poynard T., Benattar C., Bedossa P. and Chaput JC. 1994. Alpha-2macroglobulin and hepatic fibrosis: diagnostic interest. Dig Dis Sci., 1994; 39:2426-32.

33. Paradis V1., Laurent A., Mathurin P., Poynard T., Vidaud D., Vidaud M. and Bedossa P. 1996. Role of liver extracellular matrix in transcriptional and posttranscriptional regulation of apolipoprotein A-I by hepatocytes. Cell Mol Biol., 42:525-34.

34. Parkes J., Guha IN., Roderick P. and Rosenberg W. 2006. Performance of serum marker panels for liver fibrosis in chronic hepatitis C. J Hepatol., 44(3):462-474.

35. Parsian H., Alizadeh M. and Negahdar H. 2012. Would the Physicians Eventually Obsolete the Liver Biopsy for the Assessment of Liver Fibrosis? Hepat Mon., 12(5): 353-4. DOI: $10.5812 /$ hepatmon.6227.

36. Pichard A.V., Mallet V., Nalpas B., Verkarre V., Nalpas A., Venier VD., Fontaine H. and Pol S. 2007. FIB-4: an Inexpensive and Accurate Marker of Fibrosis in HCV Infection. Comparison with Liver Biopsy and FibroTest. HEPATOLOGY, 46, (1), 32-36.

37. Poynard T., Abella A., Pignon JP., Naveau S., Leluc R. and Chaput, JC. 1987. Apolipoprotein A-I and alcoholic liver disease. HEPATOLOGY;6:1391-1395.
38. Poynard T., Aubert A., Bedossa P., Abella A., Naveau S., Paraf F. and Chaput JC. 1991. A simple biological index for detection of alcoholic liver disease in drinkers. Gastroenterology; 100:1397402.

39. Regev A., Berho M., Jeffers LJ., Milikowski C., Molina EG., Pyrsopoulos NT., Feng ZZ., Reddy KR. and Schiff ER. 2002. Sampling error and interobserver variation in liver biopsy in patients with chronic HCV infection. Am. J. Gastroenterol., 97: 2614-2618.

40. Rosenberg WM1., Voelker M., Thiel R., Becka M., Burt A., Schuppan D., Hubscher S., Roskams T., Pinzani M. and Arthur MJ. 2004. Serum markers detect the presence of liver fibrosis: a cohort study. Gastroenterology, 127:17041713.

41. Ryan KJ., Ray C.G. (editors), ed. 2004. Sherris Medical Microbiology (4th ed.). McGraw Hill. pp. 551-. ISBN 0838585299. 2- Rossi EG, Cardoso LF, Ávila WS, et al. Estenose Mitral em assintomáticos. Rev Soc Cardiol Estado de São Paulo 1997;7:741-746.

42. Sabile A1, Perlemuter G., Bono F., Kohara K., Demaugre F., Kohara M., Matsuura Y., Miyamura T., Bréchot C. and Barba, G. 1999. Hepatitis C virus core protein binds to apolipoprotein AII and its secretion is modulated by fibrates. Hepatology; 30:106476.

43. Seidel C., Sundan A., Hjorth M., Turesson I., Dahl IM., Abildgaard N., Waage A. and Borset M. 2000. Serum 
syndecan-1: a new independent prognostic marker in multiple myeloma. Blood;95: 388-92

44. Shah AG., Lydecker A., Murray K., Tetri BN., Contos MJ. and Sanyal AJ. 2009. (Nash Clinical Research Network. Comparison of noninvasive markers of fibrosis in patients with nonalcoholic fatty liver disease. Clin Gastroenterol Hepatol. Oct; 7(10): 1104-12.

45. Snyder N., Gajula L., Xiao SY., Grady J., Luxon B., Lau DT., Soloway R. and Petersen J. 2006. APRI: an easy and validated predictor of hepatic fibrosis in chronic hepatitis

46. C. J Clin Gastroenterol., 40(6):535-42.

47. Stepp MA., Liu Y., Pal-Ghosh S., Jurjus RA., Tadvalkar G., Sekaran A., Losicco K., Jiang L., Larsen M., Li L. and Yuspa SH. 2007. Reduced migration, altered matrix and enhanced TGFbeta1 signaling are signatures of mouse keratinocytes lacking Sdc1. $J$ Cell Sci., 120:2851-2863.

48. Sterling RK., Lissen E., Clumeck N., Sola R., Correa MC., Montaner J., S Sulkowski M., Torriani FJ., Dieterich DT., Thomas DL., Messinger D. and Nelson M. 2006. Development of a simple noninvasive index to predict significant fibrosis in patients with $\mathrm{HIV} / \mathrm{HCV}$ coinfection. Hepatology, 43(6):1317-1325.

49. Subramanian SV., Fitzgerald ML. and Bernfield M. 1997. Regulated shedding of syndecan1 and -4 ectodomains by thrombin and growth factor receptor activation. J Biol Chem., 272: 14713-20.

50. Teare JP., Sherman D., Greenfield SM., Simpson J., Bray G., Catterall AP., Murray-
Lyon IM., Peters TJ., Williams

51. R. and Thompson RP. 1993. Comparison of serum procollagen III peptide concentrations and PGA index for assessment of hepatic fibrosis. Lancet; 342:89598.Thampanitchawong P. and Piratvisuth T 1999. Liver biopsy:complications and risk factors. World J Gastroenterol, 5:301-304.

52. Thomas DL1, Astemborski J., Rai RM., Anania FA., Schaeffer M., Galai N., Nolt K., Nelson KE., Strathdee SA., Johnson L., Laeyendecker O., Boitnott J., Wilson LE. and Vlahov

53. D. 2000. The natural history of hepatitis $\mathrm{C}$ virus infection: host, viral, and environmental factors. Jama 284: 450-456.

54. Vozar I. 2005. Serum laboratory markers for non invasive diagnosis and monitoring of liver fibrogenesis in patients with chronic liver diseases. Bratisl Lek Listy;106(3) :123- 6.

55. Wai CT1, Greenson JK., Fontana RJ., Kalbfleisch JD., Marrero JA., Conjeevaram HS. and Lok AS. 2003. A simple noninvasive index can predict both significant fibrosis and cirrhosis in patients with chronic hepatitis C. Hepatology, 38: 51826.

56. World Health Organisation 2012, mediacentre/factsheets/ fs 164/en/. Available http://www.who.int/ May 23.

57. Yang H R., Kim H R., Kim M J., Ko J S. and Seo J K. 2012. Noninvasive Parameters and hepatic fibrosis scores in children with nonalcoholic fatty liver disease. World J Gastro-enteric, 17; 18(13): 1525-30.

58. Zannis VI., Kypreos KE., 
SOHAG MEDICAL JOURNAL Leptin and Tumor necrosis factor -alpha in breast Vol. 23 No.1 Jan 2019 Asmaa Hussein.et al

Chroni A., Kardassis D, Zanni EE. 2004. Lipoproteins and atherogenesis. In: Molecular Mechanisms
Atherosclerosis.Loscalzo J (ed). Taylor \& Francis, New York, NY,

pp. 